\title{
Effects of feed colour on growth and nutrient utilization of Tilapia zillii and Oreochromis niloticus Fingerlings
}

\author{
T. Jegede* and O. D. Olusola \\ Department of Forestry, Wildlife and Fisheries, University of Ado Ekiti, Nigeria \\ Corresponding author: E-mail: temitopejegede@yahoo.com
}

\begin{abstract}
A 75-day feeding trial was conducted to determine the effects of colour additives, \{Food Drug and Cosmetic (FC and D) colour red, blue, sea-green and yellow added to a basal diet (350g crude protein and $18.5 \mathrm{KJ}$ gross energy. $\mathrm{g}^{-1}$ diet) on growth and nutrient utilization in Tilapia zillii and Oreochromis niloticus fingerlings. The control (normal light brown commercial diet, Diet 1), redcoloured diet (Diet 2), blue-coloured diet (Diet 3), sea-green coloured diet(Diet 4) and yellowcoloured diet (Diet 5) were fed to triplicate groups of $T$. zillii $(14.00 \pm 0.003 \mathrm{~g})$ and $O$. niloticus $(10.22 \pm 0.01 \mathrm{~g})$ fingerlings to apparent satiation in two equal instalments (0900-0930 and 1700-1730 h) in concrete tanks $(2 \mathrm{~m} \times 2 \mathrm{~m} \times 1.25 \mathrm{~m})$. At the end of the trial, the fish were batch-weighed. T. zillii fed yellow and sea green coloured diets had better growth performance and nutrient utilization than the other diets $(P<0.05)$. Water quality during the feeding trial was within the acceptable range for tilapia culture. Fish survival was high $(>98 \%)$ and was not affected by feed colour in both tilapias.
\end{abstract}

Keywords: Feed colour, Tilapia zillii, Oreochromis niloticus, growth, nutrient utilization.

\section{INTRODUCTION}

Tilapias constitute one of the most productive and internationally traded food fish in the world (Modadugu and Belen 2004). They are a major protein source in many of the developing countries. The commodity is not only the second most important farmed fish globally (next to carp) but also described as the most important aquaculture species of the $21^{\text {st }}$ century (Shelton 2002). Tilapia species have since been introduced in different parts of the world to improve fisheries or to develop aquaculture (Lèveque, 2002). There are about 70 species of tilapias, most of them native to rivers of western Africa (Anon 1984). Out of these, nine species are used in aquaculture worldwide among which are Oreochromis niloticus and Tilapia zillii (Hepher and Pruginin 1981, Mair 2001, FAO 2002).

Feed is the most expensive component in intensive aquaculture (El-sayed, 2004), accounting for $40-60 \%$ of the aquaculture production (ADCP, 1983; Elsayed, 1999). Proper feeding management is therefore a necessary tool in tilapia culture. Though extensive research had been conducted on the nutrient requirements and feeding regimes of farmed tilapia but the effects of feed colour on growth and nutritional utilization are yet to be fully investigated (El-Sayed 2004). Therefore, the objective of this study is to evaluate the effects of feed colour on feed acceptability, growth and nutrient utilization by $T$. zillii and $O$. niloticus.

\section{MATERIALS AND METHODS}

Diet formulation and preparation: Feedstuffs were purchased from a local market and separately milled to small particle size $(<250 \mu \mathrm{m})$ using pulverizing machine (Model BCC-2516). Five basal diets (350g crude protein $/ \mathrm{kg}$ diet; D1, D2, D3, D4, D5) were formulated (Table 1) to which was added Food Drug and Cosmetic (FD and C) colour Red (4), FD and C colour Blue (2), FD and C colour Sea-Green (3) and FD and C colour Yellow (5) to $1 \mathrm{~kg}$ of basal diet (Diet $1,350 \mathrm{~g}$ crude protein and $18.5 \mathrm{KJ}$ gross energy. $\mathrm{kg}^{-1}$ diet, respectively. The feedstuffs and the dissolved colour additives (Dyes) were thoroughly mixed in a Hobart A-200T pelleting and mixing machine. Hot water was added at intervals to gelatinize starch. All diets were pelletized using a die of $0.8 \mathrm{~mm}$ diameter. The diets were air-dried at ambient temperature for 72 hours (Plate 1); broken, sieved into small pellet sizes, packed in air-tight plastic containers, labelled and stored. Samples of the diets were analyzed for proximate composition according to AOAC (1990) methods. Crude protein was determined using a Kjeltec Auto 1003 Analyser after digestion with concentrated $\mathrm{H}_{2} \mathrm{SO}_{4}$ in a digester. Crude lipid was estimated by extracting in chloroform: methanol (2:1) using a Soxlet extraction HT6 unit. Crude fiber was 
determined using a Fibretec System 1020 Hot Extractor and ash content was determined by igniting at $550^{\circ} \mathrm{C}$ in a muffle furnace for 12 hours. Gross energy content was determined using a ballistic bomb calorimeter (Gallenkamp Co. Ltd., Loughborough, England).

Experimental system and animals: Farm-raised $T$. zillii and $O$. niloticus fingerlings were acclimated for 14 days in concrete tanks $(2 \mathrm{~m} \times 2 \mathrm{~m} \times 1.25 \mathrm{~m})$ of $600 \mathrm{~L}$ capacity. Two-thirds of each tank was filled with water. Continuous aeration was provided using a blower and air stones (Tecas air pump AP-3000) and fish were fed with a commercial pelleted diet $(30 \%$ crude protein).

After acclimation, $20 \mathrm{~T}$. zillii $(14.2 \pm 0.13 \mathrm{~g})$ or $O$. niloticus $(10.22 \pm 0.01 \mathrm{~g})$ were randomly stocked in each tank. Each treatment was replicated thrice. Feeding commenced a day after stocking and lasted 75 days. The fishes were hand-fed to apparent satiation in two equal instalments at 0900-0930 and 1700-1730 h. All fish were removed from each tank every fortnight and batch- weighed. Mortality was monitored daily and recorded.

Growth performance and nutrient utilization indices were determined as follows:

$\%$ weight gain $\left(\%\right.$. fish $\left.{ }^{-1}\right)=[($ final wt. - initial wt. $) /$ initial wt.)] x 100

weight gain $(\mathrm{g})=($ final $w \mathrm{t} .-$ initial $w \mathrm{t}$. $)$

specific growth rate $\left(\%\right.$. day- $\left.{ }^{1}\right)=[($ In final wt. - In initial wt.)/no of days] x 100

feed conversion ratio $=$ feed intake $(\mathrm{g}) /$ body weight gain $(\mathrm{g})$

Water temperature and dissolved oxygen were measured daily using a combined digital YSI DO meter (YSI model 57); $\mathrm{pH}$ was monitored weekly using an electronic $\mathrm{pH}$ meter (Metler Toledo 320 model). Two weeks before the completion of the feeding trial, faeces were collected from each tank, 8 $\mathrm{h}$ after each feeding daily. The ashes were digested by acid insoluble ash (AIA) as described by Halver et al. (1993). The value obtained for AIA was used as indicator in the calculation of digestibility coefficient. The digestibility coefficient was calculated as follows: Digestibility $=100-100(\%$ AIA in feed $) \times(\%$ nutrient in faeces $) /(\%$ AIA in faeces $)(\%$ nutrient in feeds).

Data obtained were subjected to one-way Analysis of Variance (ANOVA) test using the SPSS Version 11. Fisher's pairwise comparison was used in comparing differences among individual mean.

\section{RESULTS}

Crude protein of $35 \%$ was used in the formulation of the test diets (Table 1) and their proximate composition is presented in Table 2. Water quality during the feeding trial was within the acceptable range for tilapia culture (water temperature, $27{ }^{\circ} \mathrm{C}$; $\mathrm{pH}, 7.3$; alkalinity, $50 \mathrm{ppm}$; dissolved oxygen, 7.6 $7.9 \mathrm{mg} / \mathrm{L})$.

After 75days, T. zillii fed light-coloured diets (yellow and sea-green coloured diets) had better growth and feed efficiency $(p<0.05)$ than the other diets (Diets 1 , 2 and 3) (Table 3 and figure 1). The least growth performance was evident in fish fed the blue-coloured diet (Table 2). T. zillii survival was not affected by feed colour, as $100 \%$ survival was recorded in all treatments.

${ }^{1}$ Fish pre-mix. Colborne Dawes Nutrition Ltd., United Kingdom.: vitamin A, 1600 IU; vitamin D, 2400 IU; vitamin $\mathrm{E}, 160 \mathrm{mg}$; vitamin $\mathrm{K}, 16 \mathrm{mg}$; thiamin, $36 \mathrm{mg}$; riboflavin, $48 \mathrm{mg}$; pyridoxine, $24 \mathrm{mg}$; niacin $288 \mathrm{mg}$; panthotenic acid, $96 \mathrm{mg}$; folic acid, $8 \mathrm{mg}$; biotin, 1.3 mg; cyanocobalamin, $48 \mathrm{mg}$; ascorbic acid, $720 \mathrm{mg}$; choline chloride, $320 \mathrm{mg}$; calcium $5.2 \mathrm{~g}$; cobalt, 3.2 $\mathrm{mg}$; iodine, $4.8 \mathrm{mg}$; copper, $8 \mathrm{mg}$; iron, $32 \mathrm{mg}$; manganese, $76 \mathrm{mg}$; zinc, $160 \mathrm{mg}$; Endox (antioxidant) $200 \mathrm{mg}$.

Table 1: Ingredients composition of the basal diet (35\% crude protein)

\begin{tabular}{|l|l|}
\hline Ingredient & g/kg Diet \\
\hline Menhaden fish meal & 280 \\
\hline Soybean meal & 370 \\
\hline Yellow maize & 250 \\
\hline Cod liver oil & 30 \\
\hline Vegetable oil & 20 \\
\hline Vitamin-mineral mix & 30 \\
\hline Corn starch & 20 \\
\hline
\end{tabular}

Table 2: Proximate composition (g. $\mathrm{kg}^{-1}$ diet) of the experimental diets.

\begin{tabular}{|l|l|}
\hline & DIET \\
\hline Crude protein & 355.0 \\
\hline Ether extract & 102.2 \\
\hline Crude fibre & 17.8 \\
\hline Ash & 129.8 \\
\hline Moisture & 57.0 \\
\hline Nitrogen free extract & 318.2 \\
\hline $\begin{array}{l}\text { Gross energy } \\
\left(\mathrm{KJ} \mathrm{g}^{-1} \text { ) }\right.\end{array}$ & 18.5 \\
\hline
\end{tabular}


Agric. Biol. J. N. Am., 2010, 1(6): 1182-1186

Table 3: Growth performance and protein utilization of Tilapia zillii fingerlings fed different coloured diets.

\begin{tabular}{|l|l|l|l|l|l|}
\hline & $\begin{array}{l}\text { DIET 1 } \\
\text { (Control) }\end{array}$ & $\begin{array}{l}\text { DIET 2 } \\
\text { (Red) }\end{array}$ & $\begin{array}{l}\text { DIET 3 } \\
\text { (Blue) }\end{array}$ & $\begin{array}{l}\text { DIET 4 } \\
\text { (Sea green) }\end{array}$ & $\begin{array}{l}\text { DIET 5 } \\
\text { (Yellow) }\end{array}$ \\
\hline Final Weight (g) & $\mathrm{a}$ & $\mathrm{b}$ & $\mathrm{a}$ & $\mathrm{c}$ & $\mathrm{d}$ \\
& $25.50 \pm 1.75$ & $26.50 \pm 2.58$ & $25.25 \pm 2.58$ & $31.25 \pm 1.08$ & $33.75 \pm 0.84$ \\
\hline Initial Weight (g) & $\mathrm{a}$ & $\mathrm{a}$ & $\mathrm{a}$ & $\mathrm{a}$ & $\mathrm{a}$ \\
& $13.96 \pm 0.009$ & $13.94 \pm 0.006$ & $13.99 \pm 0.006$ & $14.05 \pm 0.010$ & $14.05 \pm 0.003$ \\
\hline Weight Gain (g) & $\mathrm{a}$ & $\mathrm{ab}$ & $\mathrm{a}$ & $\mathrm{bc}$ & $\mathrm{c}$ \\
& $11.54 \pm 16.9$ & $12.56 \pm 10.2$ & $11.26 \pm 25.1$ & $17.20 \pm 10.2$ & $19.70 \pm 8.12$ \\
\hline Weight gain (\%) & $\mathrm{a}$ & $\mathrm{ab}$ & $\mathrm{a}$ & $\mathrm{bc}$ & $\mathrm{c}$ \\
& $82.66 \pm 16.9$ & $90.10 \pm 10.2$ & $80.49 \pm 25.1$ & $122.42 \pm 10.4$ & $140.21 \pm 8.12$ \\
\hline SGR & $\mathrm{a}$ & $\mathrm{ab}$ & $\mathrm{a}$ & $\mathrm{bc}$ & $\mathrm{c}$ \\
& $0.72 \pm 0.088$ & $0.86 \pm 0.150$ & $0.79 \pm 0.067$ & $1.07 \pm 0.07$ & $1.17 \pm 0.072$ \\
& & & & & \\
\hline FCR & $\mathrm{bc}$ & $\mathrm{bc}$ & $\mathrm{c}$ & $\mathrm{ab}$ & $\mathrm{a}$ \\
& $0.053 \pm 0.14$ & $0.047 \pm 0.42$ & $0.053 \pm 0.72$ & $0.035 \pm 0.36$ & $0.031 \pm 0.80$ \\
\hline Apparent protein digestibility (\%) & 69.98 & 80.00 & 77.66 & 80.15 & 83.61 \\
\hline Survival (\%) & $100 \mathrm{a}$ & $100 \mathrm{a}$ & $100 \mathrm{a}$ & $100 \mathrm{a}$ & $100 \mathrm{a}$ \\
\hline
\end{tabular}

*values in each row having the same superscripts are not significantly different $(P<0.05)$.

*Standard error calculated from residual mean square (ANOVA)

Table 4: Growth performance and feed conversion of $O$. niloticus fed different coloured (FD \& C Dye) diets.

\begin{tabular}{|l|l|l|l|l|l|}
\hline & Control & Diet 2 (Red) & $\begin{array}{l}\text { Diet 3 } \\
\text { (Blue) }\end{array}$ & $\begin{array}{l}\text { Diet4 } \\
\text { (Sea-green) }\end{array}$ & $\begin{array}{l}\text { Diet 5 } \\
\text { (Yellow) }\end{array}$ \\
\hline Final Weight (g) & $43.16 \pm 0.10 \mathrm{c}$ & $56.74 \pm 0.40 \mathrm{e}$ & $52.26 \pm 0.10 \mathrm{~d}$ & $38.84 \pm 0.10 \mathrm{~b}$ & $32.88 \pm 0.21 \mathrm{a}$ \\
\hline Initial weight (g) & $10.21 \pm 0.01 \mathrm{a}$ & $10.23 \pm 0.01 \mathrm{a}$ & $10.21 \pm 0.01 \mathrm{a}$ & $10.23 \pm 0.01 \mathrm{a}$ & $10.22 \pm 0.01 \mathrm{a}$ \\
\hline Weight gain (g) & $32.95 \pm 0.50 \mathrm{c}$ & $46.51 \pm 0.50 \mathrm{e}$ & $42.05 \pm 0.15 \mathrm{~d}$ & $28.61 \pm 0.17 \mathrm{~b}$ & $2.66 \pm 0.23 \mathrm{a}$ \\
\hline SGR(\%) & $1.92 \pm 0.06 \mathrm{c}$ & $2.28 \pm 0.04 \mathrm{e}$ & $2.19 \pm 0.06 \mathrm{~d}$ & $1.69 \pm 0.03 \mathrm{~b}$ & $1.56 \pm 0.16 \mathrm{a}$ \\
\hline FCR & $2.43 \pm 0.02 \mathrm{c}$ & $1.20 \pm 0.01 \mathrm{e}$ & $1.80 \pm 0.01 \mathrm{~d}$ & $3.70 \pm 0.07 \mathrm{~b}$ & $6.25 \pm 0.04 \mathrm{a}$ \\
\hline $\begin{array}{l}\text { Apparent protein } \\
\text { digestibility(\%) }\end{array}$ & 71.88 & 81.37 & 77.10 & 67.49 & 64.72 \\
\hline Survival (\%) & $99 \pm 0.05 \mathrm{a}$ & $100 \pm 0.02 \mathrm{a}$ & $98 \pm 0.08 \mathrm{a}$ & $98 \pm 0.08 \mathrm{a}$ & \\
\hline
\end{tabular}

*values in each row having the same superscripts are not significantly different $(P<0.05)$.

*Standard error calculated from residual mean square (ANOVA)

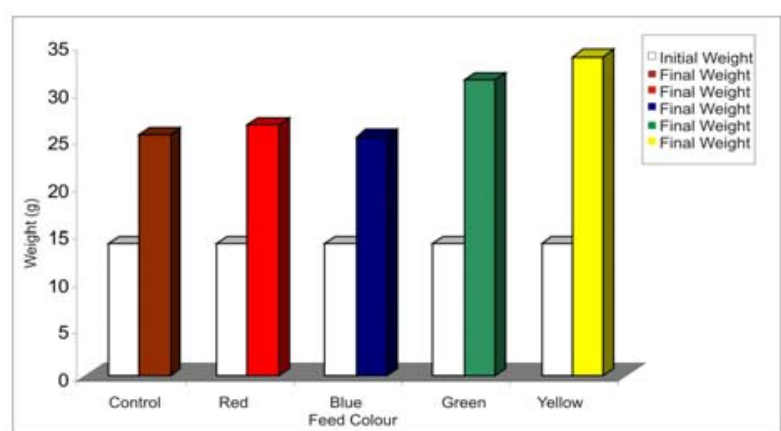

Fig 1: Effect of feed colour on weight gain in Tilapia zillii fingerlings

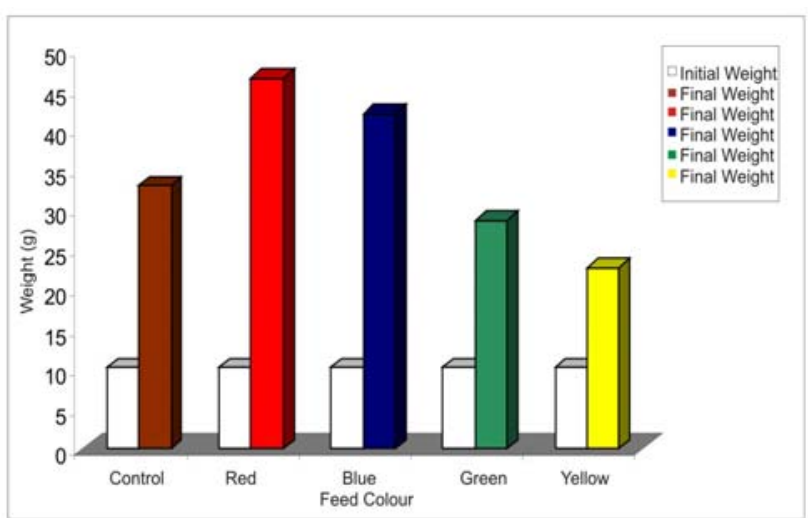

Fig 2: Effect of feed colour on weight gain in Oreochromis niloticus fingerlings

O. niloticus fed darker coloured diets (red and blue) had better growth performance and nutrient utilization $(p<0.05)$ than those fed lighter coloured diets. The red coloured diets had the best growth performance, 
followed by blue, the control and sea-green. The poorest growth performance came from $O$. niloticus fed the yellow coloured diet (Table 4 and Figure 2). $O$. niloticus survival was not affected by feed colour, as percentage survival was either greater than or equal $(\geq)$ to $98 \%$ in all the treatments.

\section{DISCUSSION}

The crude protein of $35 \%$ of the experimental diets for $T$. zillii and $O$. niloticus fingerlings (Table 1) satisfied the nutrient requirements for tilapias (Jauncey, 2000). The study revealed that $T$. zillii fed light-coloured diets (yellow and sea-green coloured diets) had better growth and feed efficiency than the other diets (Diets 1, 2 and 3 )(Table 3 and Figure 1). The least growth performance was recorded in fish fed the blue-coloured diet. This result is corroborated by Bardach et al (1980) which reported that fish generally had been proven to respond positively to colours. Traditional hook baits are now being joined by flashy chartreuse, red, blue, yellow and gold colours to add extra fish-catching attraction. Some hooks are also available with fluorescent colours that further enhance the hook's fish-catching ability. Research have also shown that red colour often triggers an attack response from game fish, while other very bright colours may simply provide some extra dazzle that also grabs the attention of a game fish on the prowl for its next meal. Clydesdale (1998) also reported that colour influences the flavour perception of food and even taste threshold. T. zillii survival was actually not affected by feed colour as $100 \%$ survival was recorded in all treatments. Water quality during the feeding trial was within the acceptable range for tilapia culture (Ross, 2000). Acceptance of the diets was good and fish became accustomed to the diets within the first week. This study therefore reveals that $T$. zillii respond positively and more favourably to light coloured diets (yellowcoloured diet and sea-green coloured diet) as against the normal commercial light-brown control diet. In a related study, $O$. niloticus fed darker coloured diets (red and blue) had better growth performance and nutrient utilization than those fed lighter coloured diets. The red coloured diets had the best growth performance, followed by blue, the control (normal light brown diet) and sea-green. The poorest growth performance came from $O$. niloticus fed the yellow coloured diet (Table 4, Fig. 2).

Fish survival was not affected by feed colour, as percentage survival was either greater than or equal to $98 \%$ in all the treatments. The trend of results obtained in this second study is similar to the preliminary study of El Sayed (2004) which reported that red and dark-blue pelletized diets seemed preferable to $O$. niloticus than light coloured diets (yellow and light green). However he recommended that additional long term studies be conducted using different size classes of tilapia to confirm the results. In this second trial, $O$. niloticus of average initial weight of $10.20 \mathrm{~g} \pm 0.01$ was used but for a longer experimental duration (75days), while in the study conducted by El Sayed (2004), O. niloticus of average initial weight of $10.5 \mathrm{~g}$ was used but for a relatively shorter period (60days).

In conclusion, $T$. zillii responded favourably to light coloured diets (yellow and sea-green) and inauspiciously to dark coloured diets, while $O$. niloticus responded favourably to dark coloured diets (red and blue) and inauspiciously to light coloured diets. Therefore, understanding the response of fish to different feed colours could be a fundamental factor in improving feed acceptance and growth performance in farmed tilapias.

\section{REFERENCES}

Aquaculture Development and Coordination Programme (ADCP) (1983). Fish feed and feeding in developing countries. An interview reports on the development programme. ADCP/REP/83/18.UNDP/FAO.

Anon. (1984) Introducing the tilapias. ICLARM Newsletter. January 1984. 7(1): 3

Association of Official Analytical Chemists (AOAC) (1990): Official methods of Analysis.16th edition, Association of Official Analytical chemists. Arlington, V. A, U.S.A.

Bardach J. E., Magnuson, J. J., May, R. C. and Reinhart J. M. (1980) Fish behaviour and its use in the capture and culture of fishes. ICLAM Conference Proceedings 5. Manila, Philippines: International Centre for Living Aquatic Resources Management, pp 512

Clydesdale F. M. (1993) Colour as a factor in food choice. Critical Reviews in Food Science and Nutrition 33 (1): $83-101$.

El-Sayed A. M. (2004) Feed colour affects growth, feed utilization of Nile tilapia. Global Aquaculture Advocate (5) pp. 49

El-Sayed A. M. (1999) Alternative dietary protein source for farmed tilapia, Oreochromis spp. Aquaculture, 179: 149-168.

FAO (Food and Agriculture Organization of the United Nations) (2007). Fishstat Plus. FAO, Rome

FAO (Food and Agriculture Organization of the United Nations) (2002). Fishery Statistics. Aquaculture production. 90(2). 
FAO (Food and Agriculture Organization of the United Nations) (1998)

http://www.fao.org/waicent/faoinfo/fishery/fishery html. Fisheries statistics 1998

Halver J. E., Yiman A. and Smith R. R. (1993) Acid insoluble ash as a convenient method for estimating digestible component in diet. Abstract of contribution presented at the International Conference World Aquaculture. Freshw. Fish Posters.

Hepher B. and Pruginin, Y. (1981) Commercial fish farming with special reference to fish culture in Israel. John Wiley and Sons, New York, USA.

Jauncey, K. (2000) Nutritional requirements. Pp.327-375 in M.C.M. Beveridge and B.J. McAndrew (eds.) Tilapias: biology and exploitation. Academic Publishers. UK.

Lèveque C. (2002) Out of Africa: the success story of tilapias. Environmental Biology of Fishes. 64 : 461464. Kluwer Academic publisher. Netherlands.
Mair G. (2001) Genetics in tilapia aquaculture. Tilapia production in the Americas. P. 136 - 148. In Subasinghe $S$. and S. Tarlochan(eds.)Tilapia: Production, marketing and technological developments. Proceedings of the Tilapia 2001 International Technical and Trade Conference on Tilapia, 28- 31.May 2001, Kaala Lumpur, Malaysia.

Modadugu V. G. and Belen O. A. (2004) A review of global tilapia farming practices. Aquaculture Asia Vol. IX. No 1. pp 1- 16.

Ross L. G. (2000) Environmental physiology and energetic. pp. 89-128 in M. C. M. Beveridge and B. J. McAndrew, B. J.(eds.) Tilapias: biology and exploitation. Kluwer Academic Publishers. UK.

Shelton W. L. (2002) Tilapia culture in the $21^{\text {st }}$ century p. 120. In Gurrero R. D. III and M. R. Guerrero-del Castillo (eds.) Proceedings of the International Forum on Tilapia Farming in the $21^{\text {st }}$ Century (Tilapia Forum 2002), 184p. Philippine Fisheries Association Inc. Los Bonos, Laguna, Philippines. 